\title{
自己充てん型高強度高耐久コンクリートを用いた 構造物の研究開発動向
}

\author{
渡部 正*1 •三島 徹也*2 ・鬼頭 誠*3
}

\begin{abstract}
概 要 構造物の長寿命化技術として, 自己充てん型高強度高耐久コンクリートが実用化の段階を迎えている。自己充 てん型高強度高耐久コンクリートは超高性能コンクリートとも呼ばれており，水結合材比 $40 \%$ 以下で設計基準強度 $60 \mathrm{~N}$ $/ \mathrm{mm}^{2}$ 以上の高強度が期待され, 自己充てん性を有するコンクリートと定義される。超高性能コンクリートと引張強度 $700 \mathrm{~N} / \mathrm{mm}^{2}$ 以上の高強度鉄筋などを組み合わせた部材の構造性能, 耐久性能について試験結果に基づく新たな知見が得 られており，その研究成果のとりまとめとして設計・施工指針（案）がおおむね完成している。同指針の特徵としては, 1）性能照査型指針である，2）設計，施工，維持管理マニュアルが完備されている，3）試設計例が明示されている，な どがあげられる。

キーワード : 長寿命化, 超高性能コンクリート, 自己充てん, 高強度, 高耐久, 性能照査, 設計, 施工, 維持管理
\end{abstract}

1.はじめに

近年，コンクリート構造物の劣化対策等による維持管 理費用の増加に伴って，構造物の長寿命化技術の一つで ある自己充てん型高強度高耐久コンクリートが注目され ている。自己充てん型高強度高耐久コンクリートは超高 性能コンクリート（以下， S. Q. C=Super Quality Concrete）とも呼ばれており，「水結合材比 $40 \%$ 以下 で設計基準強度 $60 \mathrm{~N} / \mathrm{mm}^{2}$ 以上の高強度が期待され， 施工欠陥を生じさせないような良好な充てん性を持つコ ンクリート」と定義されている。超高性能コンクリート と高強度鉄筋などを使用し，必要に応じて鋼繊維補強を 行ったコンクリート構造物は「超高性能コンクリート （S. Q. C）構造物」と呼ばれる。S.Q.C 構造物はイニシャ ルコストの点で従来の $\mathrm{RC}$ 構造物亡同等であり, 耐久性 が高いことから，メンテナンスコストを含めたライフサ イクルコストは大幅に改善される。

これまで, S. Q. C 構造物開発・普及協会を中心に, 超高性能コンクリート構造物の耐久性, 耐震性などの性 能検証に関する実験的研究がなされており，その基本的 な性状はある程度把握されつつある。またこれらの研 究成果を取り入れた性能照查型の設計・施工指針（案） が, 土木学会コンクリート委員会の指導の下, 平成 12 年度に完成予定である。さらに, 本技術はミレニアムプ ロジェクト（科学技術庁の公募課題）に採択され, 今後 3 年間, さらなる発展に向けた研究が追加実施される予 定である。

\footnotetext{
＊1 わたなべ・ただし/S. Q. C 構造物開発・普及協会（前田建設工 業(搳) 技術研究所 課長)

＊2 みしま・てつや/S. Q. C 構造物開発・普及協会（前田建設工業 (侏) 技術研究所 課長代理)

*3 きとう・まこと/S. Q. C 構造物開発・普及協会（侏長大 理事)
}

そこで本報では，これまでに実施された耐久性能や耐 震性能の確認試験について概括するとともに, 性能照査 型設計・施工指針の概要を紹介する。

\section{2. 超高性能コンクリート構造物の特徵}

\section{1 超高性能コンクリートの配合と使用材料}

一般に，高流動コンクリートは粉体系, 増粘剤系, 併 用系に分類されるが，S. Q. C は主に粉体系を使用する。 配合例は表-1に示すとおりである。先に紹介した設計・ 施工指針（案）では，S. Q. C の品質を以下のように規 定している。

1）コンクリートは自己充てん性を有するものでなけ ればならない。

2）コンクリートの水結合材比は $40 \%$ 以下を基本と する。

3）コンクリートの自己収縮量は $200 \times 10^{-6}$ 以下（材 齢 28 日）を基本とする。

4）コンクリートの設計基準強度は $60 \sim 100 \mathrm{~N} / \mathrm{mm}^{2}$ （材歯 56 日）を基本とする。

主な使用材料は以下のとおりである。

セメント：ビーライト系のセメントあるいは混和材混 入セメントを使用する。単位セメント量が多くなるので, 低発熱夕イプのセメントを用いるのが基本である。

骨材：耐久的で堅硬な砕石を主に使用する。単位セメ ント量が多くなるので, アルカリ骨材反応に対しては安 定な骨材を使用する必要がある。

混和剂：高性能 $\mathrm{AE}$ 減水剂を使用する。空気量は 3〜 4\% とするが，耐凍結融解性を高める場合には $6 \%$ 程度とする。

\section{2 材料単価と建設費用}

S. Q. C 構造物に用いられる主材料は，高強度鉄筋 


\begin{tabular}{|c|c|c|c|c|c|c|c|c|c|c|c|c|c|c|c|}
\hline \multirow{3}{*}{ 配合名 } & \multirow{3}{*}{ 配合強度 } & \multirow{3}{*}{$\begin{array}{l}\text { 粗骨材の } \\
\text { 最大寸法 }\end{array}$} & \multirow[b]{3}{*}{$\begin{array}{l}\text { 目 標 } \\
\text { スランプ } \\
\text { フロ } \\
\\
(\mathrm{mm})\end{array}$} & \multirow{3}{*}{$\begin{array}{c}\text { 水結合材 } \\
\text { 比 }\end{array}$} & \multirow{3}{*}{$\begin{array}{l}\text { 目 標 } \\
\text { 空気量 }\end{array}$} & \multicolumn{10}{|c|}{ 単位量 $\left(\mathrm{kg} / \mathrm{m}^{3}\right)$} \\
\hline & & & & & & \multirow[b]{2}{*}{ 水 } & \multirow[b]{2}{*}{ セメント } & \multicolumn{3}{|c|}{ 混和材 } & \multirow[b]{2}{*}{ 細骨材 } & \multirow[b]{2}{*}{ 粗骨材 } & \multicolumn{2}{|c|}{ 混和剂 } & \multirow[b]{2}{*}{ 鋼繊維 } \\
\hline & & & & & & & & $\begin{array}{c}\text { フライ } \\
\text { アッシュ } \\
\text { FA }\end{array}$ & $\begin{array}{c}\text { 高 炉 } \\
\text { スラグ } \\
\text { 微粉末 } \\
\text { BS }\end{array}$ & 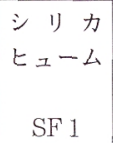 & & & $\begin{array}{l}\text { 高性能 } \\
\mathrm{A} \quad \mathrm{E} \\
\text { 減水剂 }\end{array}$ & $\mathrm{AE}$ 剂 & \\
\hline LC 72 & 72 & 20 & 600 & 38.6 & 4.0 & 165 & 427 & & & & 891 & 827 & 4.27 & 8.5 & \\
\hline FA 72 & 72 & 20 & 600 & 34.9 & 4.0 & 165 & 378 & 95 & & & 809 & 827 & 5.91 & 35.5 & \\
\hline BS 72 & 72 & 20 & 600 & 41.5 & 4.0 & 165 & 199 & & 199 & & 891 & 827 & 4. 18 & 10.0 & \\
\hline BL 96 & 96 & 20 & 650 & 32.6 & 3.5 & 165 & 506 & & & & 852 & 811 & 6.83 & 10.1 & \\
\hline SF 120 & 120 & 20 & 650 & 25.7 & 3.0 & 165 & 578 & & & 64 & 750 & 795 & 12.84 & 51.4 & \\
\hline BS 120 & 120 & 20 & 650 & 22.0 & 3.0 & 165 & 675 & & 75 & & 681 & 795 & 13.13 & 9.0 & \\
\hline SFRC & 72 & 20 & 600 & 28.9 & 5.5 & 165 & 571 & & & & 1039 & 510 & 11. 40 & 15.4 & 80 \\
\hline
\end{tabular}

（USD 685 ほか）とS.Q.Cである。現状では，高強度 鉄筋が普通電炉鉄筋の約 2.5 倍強, S. Q.C が普通のコ ンクリートの 1.5〜2.5 倍（地域差が大きい）の材料単 洒となっており，材料費は一般に高くなる。

\begin{tabular}{|c|c|c|}
\hline & 在来構 & Q.C構 \\
\hline 工事費比率 & 1.00 & 0.97 \\
\hline 上部工 & & \\
\hline & 在来構 & Q.C構 \\
\hline 重 量 比 & 1.00 & 0.90 \\
\hline 工事費比率 & 1.00 & 0.99 \\
\hline 橋 脚 & & \\
\hline & 在来構 & Q.C構造 \\
\hline 重 量 比 & 1.00 & 0.7 \\
\hline 工事費比摔 & 1.00 & 1.03 \\
\hline 基礎ぐい & & \\
\hline & 在来構 & Q.C構. \\
\hline $\begin{array}{l}\text { コンクリート } \\
\text { 体積比率 }\end{array}$ & 1.00 & 0.63 \\
\hline 工事費比率 & 1.0 & 0.81 \\
\hline
\end{tabular}

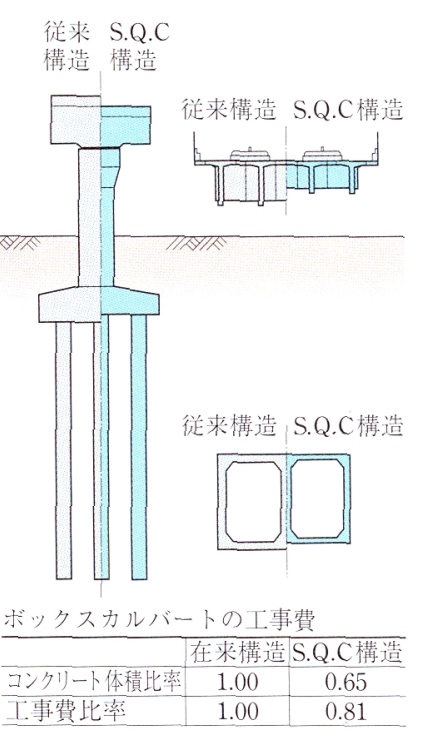

図-1 試設計とコスト比較
一方, S. Q. C 構造物開発・普及協会では, 種々の条件 で試設計とコス卜試算を行っている。構造物の断面縮小 が可能などの条件が整えば，コンクリート打設量や掘削 土量が低減されるため，建設費レベルで S. Q. C 構造物 の方が安くなるとの試算結果が得られている。図-1に 橋脚およびボックスカルバートのコスト比較結果を示す。

3. 構造性能

\section{1 耐震 性 能}

\section{(1) 試験概要}

S. Q. C 柱部材の変形性能を定量化する目的で，正負 交番載荷試験を行った報告が近藤ら ${ }^{1)}$ (2) によってなされ ており，ここでその概略を紹介する。試験には，2.1に 示した材料を用いており, 図-2にその試験体の外観, 断面および載荷位置を示す。試験の主なパラメー夕は, 軸方向鉄筋比, せん断余裕率 $(V \cdot L / M, V:$ せん断耐 力, $L$ : せん断スパン, $M$ : 曲げ耐力）としている。軸 力は原則として各試験体のコンクリート設計基準強度の 10\% 相当であるが，縮小断面のNo. 9 試験体について はNo.0 と同一軸力での比較が行えるように, 軸応力を

Technical Trend for Development of Structures Using Self-Compacting Concrete with High-Strength and High Durability

By T. Watanabe, T. Mishima and M. Kitou

Concrete Journal, Vol. 39, No.2, pp. 14 21, Feb. 2001

Synopsis Self-compacting concrete with high strength and high durability has been on the practical stage as a technique extending the life span of structures. Self-compacting concrete with high strength and high durability is also called Super Quality Concrete (S. Q. C), which is defined as concrete with W/B less than 40\%, expected compressive strength more than $60 \mathrm{~N} / \mathrm{mm}^{2}$ and having self compacting workability. The new technical information about mechanical properties and durability performance of members combined Super-Quality-Concrete and deformed-bar with high strength more than $700 \mathrm{~N} / \mathrm{mm}^{2}$ has been recently obtained through various experiments. Reflecting these experimental results, the guideline for design and construction has been almost completed and will be published soon. Advanced points of this guideline are 1) it is based on performance evaluation technique, 2) it includes Design, Construction, and Maintenance Manual, 3) an example of trial design is included as an appendix, and so on.

Keywords : long life span, Super Quality Concrete, self compacting, high strength, high durability, performance evaluation, design, construction, maintenance 

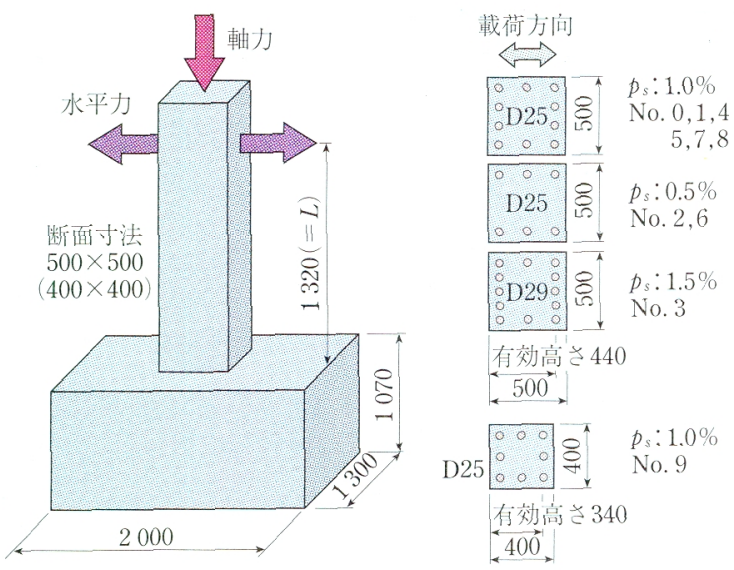

図-2＼cjkstart試験体外観および断面寸法

4. $69 \mathrm{~N} / \mathrm{mm}^{2}$ に設定している。

(2) 試験結果

図-3に，試験結果の一つとして代表的な試験体の曲 げモーメント一変位関係を示す。No. 1 試験体は，No. 0 試験体と同等の軸方向鉄筋比で高強度材料を用いた試験 体である。試験結果より，No.0 試験体に比較し，降伏 耐力 $M_{y}$ は軸方向鉄筋の降伏強度に比例して大きくなっ ているが，終局変位はほぼ同等となっている。このこと より，S.Q.C 柱部材においては，変形性能を犠牲にす ることなく，部材強度の向上が可能であり，通常の $\mathrm{RC}$ 部材に比べエネルギ一吸収能力が向上し，耐震性に優れ ることがわかる。No.9 試験体は，No. 0 試験体とほほ 同等の曲げ耐力を有するよう断面を縮小したものである が，No. 0 試験体の同等以上の変形性能を有している。

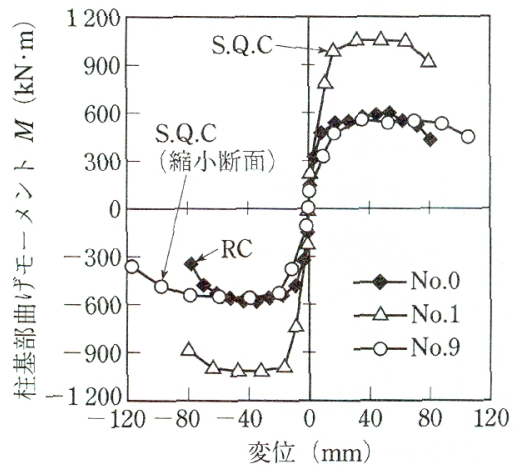

図-3 曲げモーメント-変位関係

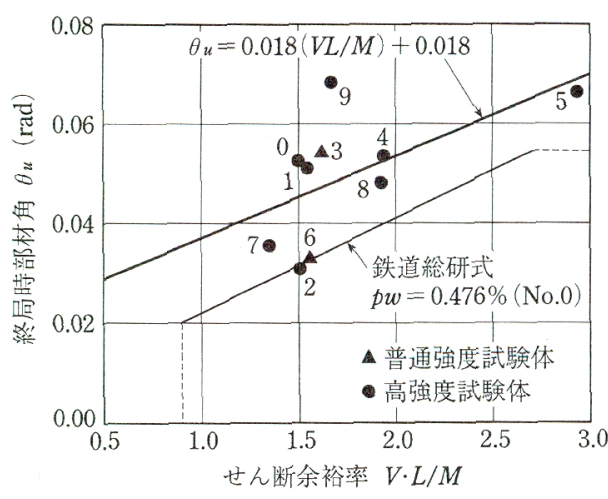

図-4 せん断余裕率之終局部材回転角
このことより，S.Q.C 部材の場合，通常 RC 部材に対 して断面積を 60〜 70\%に縮小しても，部材耐力ならび に変形性能を同等に保つことが可能であり，構造物の軽 量化が図れるとともに耐震性能も向上すると言える。な お，ここに示した 3 試験体では，せん断余裕率 $=1.5$ の 一定としており，No.0，1，9試験体の帯鉄筋の種類お よび間隔はそれぞれ，D $10(\mathrm{SD} 345)$ を $6 \mathrm{~cm}$ 間隔，D 10 （USD 785）を $6 \mathrm{~cm}$ 間隔，D 10 (USD 785）を $9 \mathrm{~cm}$ 間隔となっている。

（3）変形性能

図-4に，終局部材回転角とせん断余裕率の関係を示 す。せん断スパン比が若干異なるNo.9 試験体がやや高 い変形性能を有する傾向にあるが，その他試験体に関し ては，せん断余裕率上終局部材回転角の間には，ある程 度の相関関係が認められ，式-1で表される関係が成り 立つとしている。式-1に関しては，実施されている試 験体と同程度のせん断スパン比（約 3.0）を有する S. Q. C 部材の変形性能を簡便に算出する設計式として 十分使用できるもの上考えられる。

$$
\theta_{u}=0.018 \cdot(\mathrm{V} \cdot L / M)+0.018 \cdots \cdots \cdots \cdots \cdots \cdot \text { 式 }-1
$$

「鉄道構造物等設計標準・同解説 而震設計」では, 被災後の損傷レベルを考慮した耐震設計法を取り入れて いる。S.Q.C部材に対して同指針を適用可能であれば， S. Q. C 部材の特徴をさらに活かした設計が可能となる。 例えば，S. Q. C 部材では高強度材料を用いることによ り，過密配筋とすることなく部材の降伏強度を高く設定 できるため，構造物の重要度に応じて被災後の損傷程度

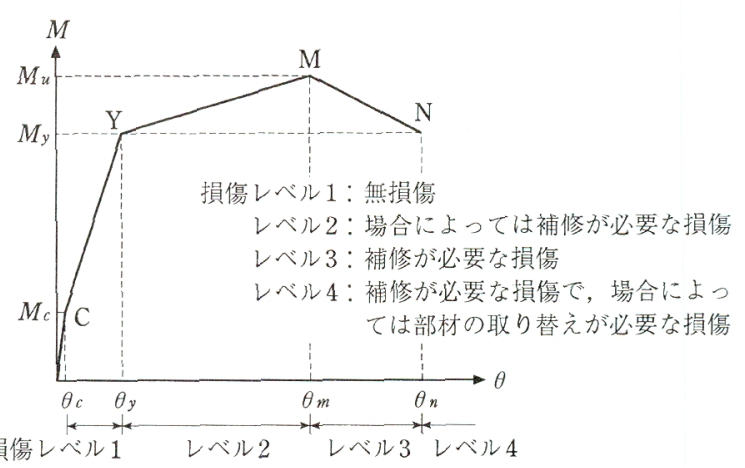

図-5＼cjkstart損傷レベルと荷重-変位関係

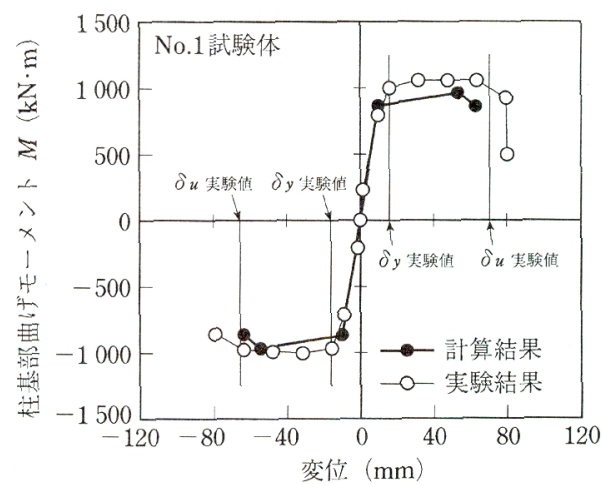

図-6 荷重-変位関係の例（S. Q. C 試験体） 
を抑えた設計を容易に実現できる。各損傷レベルと荷重 -変位関係の対応は図-5に示すとおりである。また, 図-6に一例として, No. 1 試験体の実験值と算定值の比 較を示す。同指針の変形性能算定式による S. Q. C 部材 の各損傷レベルでの変形量はおおむね妥当に評価されて おり，同指針が S. Q. C 部材にも適用可能であることが 確認できる。

\section{2 せん断強度}

高強度材料を用いた RC 部材のせん断耐力は, 合理的 な評価方法が確立されていないのが現状であるが，近年 研究が盛んに実施されており，データも蓄積されてきつ

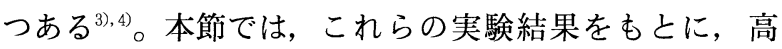
強度材料を用いた場合のせん断耐力評価に関し，合理的 な設計方法の検討を行う。なお，No. 1 4 試験体は著 者らが新たに実施した試験体である。

土木学会コンクリート標準示方書では, 材料強度に関 して, $f_{v c}=0.20 \bullet f_{c}^{\prime 1 / 3} \leqq 0.72 \mathrm{~N} / \mathrm{mm}^{2}, f_{w y} \leqq 400 \mathrm{~N} / \mathrm{mm}^{2}$ という制限值が設けられている。 $V_{c}$ (女ん断補強鉄筋を 用いない棒部材のせん断耐力）の実験值はコンクリート 強度が大きくなるにつれて，算定值よりわずかに低下す る傾向が見られるため，コンクリート強度に関しては, 同様の制限が必要と考えられる（式-2）。しかしながら， 表-2 に示すように, $f_{w y} \leqq 400 \mathrm{~N} / \mathrm{mm}^{2}$ の制限を適用する と, 算定值はせん断耐力 $V_{y}$ を過小評価する傾向が見ら
れる。したがって， $V_{s}$ (せん断補強鉄筋の受け持つせん 断耐力）に関しては，上限值を試験体に使用されている $785 \mathrm{~N} / \mathrm{mm}^{2}$ に変更しても問題ないと考えられる（式-3）。 表-2に，これら制限值を適用した算定值と実験值を比 較した結果を示す。

$$
\begin{aligned}
& f_{v c}=0.20 \sqrt[3]{f_{c}^{\prime}} \leqq 0.72\left(\mathrm{~N} / \mathrm{mm}^{2}\right) \cdots \cdots \cdots \cdots \cdot \text { 式 }-2 \\
& f_{w y} \leqq 785\left(\mathrm{~N} / \mathrm{mm}^{2}\right) \cdots \cdots \cdots \cdots \cdots \cdots \cdots \cdots \cdots \cdots \cdots \cdots \cdots \cdot \text { 式 }-3
\end{aligned}
$$

同表に示すように，設定した制限值により，各試験体 のせん断耐力は安全側で評価されている。なお，式-2 中の $f_{c}^{\prime}$ に関する材料係数 $\gamma_{c}$ について 土木学会コン クリート標準示方書では $60 \mathrm{~N} / \mathrm{mm}^{2}$ 以上のコンクリー トに対しては $\gamma_{c}=1.5$ が用いられるのに対して, S. Q. C の場合, 自己充てん性を有することによって品質が安定 していることから， $\gamma_{c}=1.3$ への変更が検討されている。 同表に示す算定值のばらつきは比較的少なく，せん断強 度に関しては, $\gamma_{c}=1.3$ としても, 十分安全であると思 われる。

\section{3 継手強度}

伊藤らは，重ね継手を等曲げモーメント区間に有する はり試験体を用いて, S. Q. C 部材の基本定着長に関す る検討を行っている5 ${ }^{5}$ 。その中で伊藤らは，付着強度の 実験値とコンクリート標準示方書による算定值を比較し, S. Q. C 部材においては, 現状の付着強度を若干低減す る必要があることを報告している。表-3に，実施され

\begin{tabular}{|c|c|c|c|c|c|c|c|c|c|c|c|c|}
\hline \multirow{3}{*}{ No. } & \multicolumn{6}{|c|}{ 使 用 材 料 } & \multicolumn{2}{|c|}{ 形状寸法 } & \multicolumn{4}{|c|}{ 実験值と計算値の比較 } \\
\hline & \multirow[b]{2}{*}{$\begin{array}{c}f_{c}^{\prime} \\
\left(\mathrm{N} / \mathrm{mm}^{2}\right)\end{array}$} & \multicolumn{2}{|c|}{ 主 鉄 筋 } & \multicolumn{3}{|c|}{ せん断補強鉄筋 } & \multirow[b]{2}{*}{$\begin{array}{c}d \\
(\mathrm{~mm})\end{array}$} & \multirow[b]{2}{*}{$\begin{array}{c}b_{w} \\
(\mathrm{~mm})\end{array}$} & \multicolumn{2}{|c|}{ 土木学会 } & \multicolumn{2}{|c|}{ S. Q. C 指針 } \\
\hline & & $\begin{array}{c}f_{y} \\
\left(\mathrm{~N} / \mathrm{mm}^{2}\right) \\
\end{array}$ & $\begin{array}{c}A_{s} \\
\left(\mathrm{~mm}^{2}\right) \\
\end{array}$ & $\begin{array}{c}f_{y} \\
\left(\mathrm{~N} / \mathrm{mm}^{2}\right)\end{array}$ & $\begin{array}{c}A_{s} \\
\left(\mathrm{~mm}^{2}\right) \\
\end{array}$ & $\begin{array}{c}S_{s} \\
\left(\mathrm{~mm}^{2}\right) \\
\end{array}$ & & & $\frac{V_{\text {cexp }}}{V_{c \text { cal }}}$ & $\frac{V_{y \exp }}{V_{y \text { cal }}}$ & $\frac{V_{\text {cexp }}}{V_{c \text { cal }}}$ & $\frac{V_{y \text { exp }}}{V_{y \text { cal }}}$ \\
\hline No. 1 & 51.0 & 698 & 2569.6 & - & - & - & 350 & 350 & 1.33 & 1.33 & 1.33 & 1.33 \\
\hline No. 2 & 49.4 & 698 & 2569.6 & 747 & 63.3 & 100 & 350 & 350 & 1.22 & 1.70 & 1.22 & 1.31 \\
\hline No. 3 & 55.2 & 698 & 2569.6 & 747 & 63.3 & 75 & 350 & 350 & 1.27 & 1.75 & 1.27 & 1.29 \\
\hline No. 4 & 51.0 & 699 & 2569.6 & 803 & 142.7 & 200 & 350 & 350 & 1.15 & 1.61 & 1.15 & 1.19 \\
\hline No. 5 & 75.0 & 742 & 5559.4 & 1048 & 142.7 & 200 & 400 & 600 & - & 2.32 & - & 1.86 \\
\hline No. 6 & 78.1 & 742 & 4765.2 & 1048 & 142.7 & 200 & 400 & 525 & - & 2.20 & - & 1.73 \\
\hline No. 7 & 78.2 & 742 & 3971.0 & 1048 & 142.7 & 200 & 400 & 435 & - & 2.42 & - & 1.85 \\
\hline No. 8 & 79.5 & 742 & 3176.8 & 982 & 253.4 & 300 & 400 & 350 & - & 1.74 & - & 1.24 \\
\hline No. 9 & 79.7 & 742 & 5559.4 & - & - & - & 400 & 600 & 1.11 & 1.11 & 1.11 & 1.11 \\
\hline No. 10 & 79.1 & 742 & 4765.2 & - & - & - & 400 & 525 & 1.16 & 1.16 & 1.16 & 1.16 \\
\hline No. 11 & 77.3 & 742 & 3971.0 & - & - & - & 400 & 435 & 1.04 & 1.04 & 1.04 & 1.04 \\
\hline No. 12 & 75.9 & 742 & 3176.8 & - & - & - & 400 & 350 & 1.01 & 1.01 & 1.01 & 1.01 \\
\hline No. 13 & 69.5 & 711 & 573.0 & - & - & - & 260 & 150 & 1.07 & 1.07 & 1.07 & 1.07 \\
\hline No. 14 & 29.4 & 711 & 573.0 & - & - & - & 260 & 150 & 1.01 & 1.01 & 1.01 & 1.01 \\
\hline No. 15 & 69.5 & 333 & 573.0 & - & - & - & 260 & 150 & 1.05 & 1.05 & 1.05 & 1.05 \\
\hline No. 16 & 29.4 & 333 & 573.0 & - & - & - & 260 & 150 & 1.21 & 1.21 & 1.21 & 1.21 \\
\hline No. 17 & 69.5 & 1050 & 570.6 & - & - & - & 240 & 150 & 1.09 & 1.09 & 1.09 & 1.09 \\
\hline No. 18 & 29.4 & 1050 & 570.6 & - & - & - & 240 & 150 & 1.33 & 1.33 & 1.33 & 1.33 \\
\hline No. 19 & 69.5 & 363 & 570.6 & - & - & - & 240 & 150 & 1.06 & 1.06 & 1.06 & 1.06 \\
\hline No. 20 & 29.4 & 363 & 570.6 & - & - & - & 240 & 150 & 1.26 & 1.26 & 1.26 & 1.26 \\
\hline No. 21 & 69.5 & 711 & 573.0 & - & - & - & 260 & 150 & 0.98 & 0.98 & 0.98 & 0.98 \\
\hline
\end{tabular}

表-2＼cjkstart算定值と実験值の比較

* No. 5 12 試験体は, 新田ら ${ }^{3)}$, No. 13〜21 試験体は土屋ら $ら^{4)}$ の報告を参照した 
表-3 試験体一覧

\begin{tabular}{|c|c|c|c|c|c|c|c|c|}
\hline \multirow{2}{*}{ 試験体 } & \multicolumn{3}{|c|}{ 鉄 筋 } & \multirow{2}{*}{\begin{tabular}{|c|} 
コンク \\
リート \\
強 $\quad$ 度 \\
$\left(\mathrm{N} / \mathrm{mm}^{2}\right)$
\end{tabular}} & \multirow{2}{*}{$c_{b}$} & \multirow{2}{*}{$\alpha_{b}$} & \multirow{2}{*}{$\begin{array}{c}\text { 継手長 } \\
l / \phi\end{array}$} & \multirow{2}{*}{ パラメータ } \\
\hline & 主鉄筋 & 横補強釷 & 泆筋 & & & & & \\
\hline $\mathrm{K} 1$ & \multirow{4}{*}{$\begin{array}{c}\text { D } 19 \\
\text { 降伏強度 } \\
720 \\
\left(\mathrm{~N} / \mathrm{mm}^{2}\right)\end{array}$} & \multirow{4}{*}{$\begin{array}{c}\text { D 10 } \\
\text { 降伏強度 } \\
972 \\
\left(\mathrm{~N} / \mathrm{mm}^{2}\right)\end{array}$} & - & 88.1 & 30 & 0.68 & 24.4 & \multirow{3}{*}{$\begin{array}{l}\text { 横方向鉄筋 } \\
\text { 量 }\end{array}$} \\
\hline $\mathrm{K} 2$ & & & @150 & 88.1 & 30 & 0.58 & 21.1 & \\
\hline K 3 & & & @60 & 89.5 & 30 & 0.50 & 18.1 & \\
\hline K 4 & & & @150 & 89.5 & 30 & 0.58 & 24.3 & $\begin{array}{l}\mathrm{K} 2 \text { 継手長 } \\
\text { の } 1.15 \text { 倍 }\end{array}$ \\
\hline
\end{tabular}

\section{表-4 試験結果}

\begin{tabular}{|c|c|c|c|c|c|c|}
\hline \multirow[b]{2}{*}{ 試験体 } & \multirow[b]{2}{*}{ 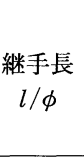 } & \multirow[b]{2}{*}{$\alpha_{b}$} & \multirow[b]{2}{*}{$\begin{array}{c}\text { コンクリート } \\
\text { 強度 } \\
\left(\mathrm{N} / \mathrm{mm}^{2}\right)\end{array}$} & \multicolumn{2}{|c|}{ 付着強度 } & \multirow{2}{*}{$\begin{array}{c}\text { 実験値 } \\
\text { 計算値 } \\
\beta\end{array}$} \\
\hline & & & & $\begin{array}{c}\text { 実験值 } \\
f_{b 0 \exp } \\
\left(\mathrm{N} / \mathrm{mm}^{2}\right)\end{array}$ & $\begin{array}{c}\text { 計算值 } \\
f_{b 0 \text { cal }}{ }^{* 1} \\
\left(\mathrm{~N} / \mathrm{mm}^{2}\right)\end{array}$ & \\
\hline K 1 & 24.4 & 0.68 & 88.1 & 4. 59 & 5. 54 & 0.83 \\
\hline K 2 & 21.1 & 0.58 & 88.1 & 4.97 & 5. 54 & 0.90 \\
\hline K 3 & 18.1 & 0.50 & 89.5 & 5. 39 & 5. 60 & 0.96 \\
\hline K 4 & 24.3 & 0.58 & 89.5 & 4. 83 & 5.60 & 0.86 \\
\hline
\end{tabular}

*1 土木学会コンクリート標準示方書 $f_{b 0}=0.28 f_{c}^{\prime 1 / 3}$

\section{た試験体の一覧を示す。}

表-4に, 試験結果の一覧を示す。試験では平均で約 1 割程度実験值が下回る結果が得られている。そこで,

S. Q. C の付着強度算定式として, 低減係数 $\beta(=0.89$ : 全試験体平均値)を考慮した式-4 が提案されている。 なお，付着強度に対する材料係数 $\gamma_{c}$ については，図-7 に示すように，せん断強度と同様に $\gamma_{c}=1.3$ としても， 十分安全であることが確認できる。

$$
\begin{aligned}
& f_{b 0}=\beta \cdot\left(0.28 f_{c}^{\prime 2 / 3} / \gamma_{c}\right) \\
& \beta=0.89, \gamma_{c}=1.3
\end{aligned}
$$

4. 耐久性能および照查方法について

コンクリート構造物の耐久性に最も大きく関与するの は，鋼材の腐食である。鋼材の腐食をもたらす因子とし ては, ひび割れ, 中性化, 塩化物イオンの侵入, 酸性雨 による侵食, 凍結融解, 化学的侵食およびアルカリ骨材 反応等がある。コンクリートあるいはコンクリート構造 物の長期耐久性に対する照査を行うえでは，それら因子 による劣化予測を定式化する必要がある。以下に，自己 充てん型高強度高耐久コンクリートの中性化速度, 凍結 融解抵抗性, 酸性雨に対する抵抗性を対象とした試験結 果の概要および劣化の予測式について述べる ${ }^{6) \text { 8) }}$

\section{1 中 性 化}

自己充てん型高強度高耐久コンクリートは，水結合材 比が 40\% 以下を基本としているため，硬化コンクリー トの組織が緻密であり，中性化に対する抵抗性は通常の コンクリートよりも優れている。図-8に, 水結合材比 $40 \%$ 以下の自己充てん型高強度高耐久コンクリートの 促進中性化試験結果を示す。これは，各種配合において，

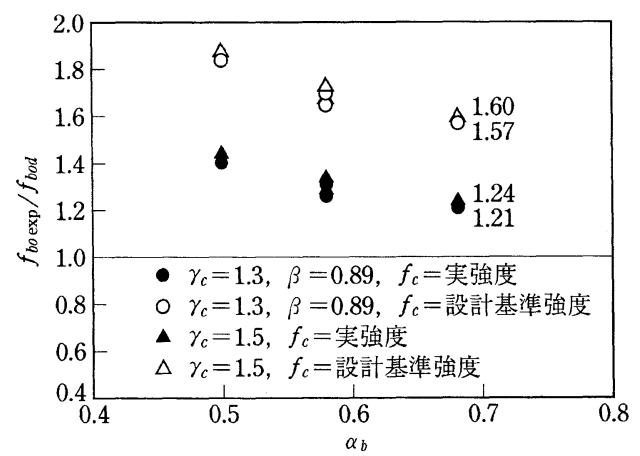

図-7 設計付着強度の比較

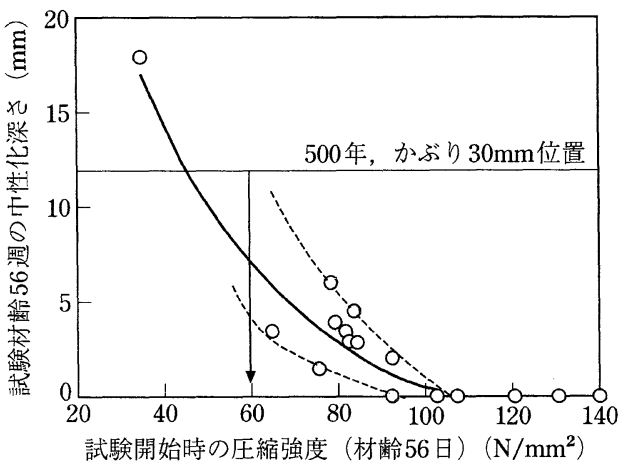

図-8＼cjkstart超高性能コンクリートの促進中性化試験結果

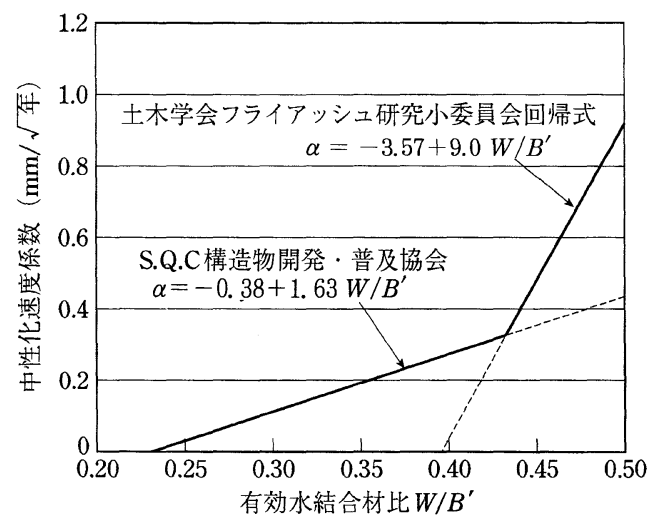

図-9 中性化速度係数ट有効水結合材比亡の関係

炭酸ガス濃度 $5 \%$ の下で材齢 56 日より促進中性化試験 を開始し, その時の压縮強度を横軸にとり, 縦軸に促進 期間 26 週での中性化深さを表したものである。これに よれば，試験開始時の圧縮強度が大きくなるに従って中 性化深さが急激に小さくなることが分かる。日本建築学 会「高耐久性コンクリート造設計・施工指針（案）」に 準じて試算すると, 一般環境で中性化深さが $30 \mathrm{~mm}$ に 達するのは促進材齢 26 週で $12 \mathrm{~mm}$ に相当する。これは, コンクリート構造物の供用期間が 500 年に相当する。

同様に，促進中性化試験時の炭酸ガス濃度 $5 \%$ を大気 中の值に換算して中性化速度係数を求めて有効水結合材 比との関係を示したものが図-9 である。これより, 中 性化自己充てん型高強度高耐久コンクリートの速度係数 $\alpha$ は，式-5 にて予測することができる。

$\alpha=-0.38+1.63 \mathrm{~W} / B^{\prime}(\mathrm{mm} / \sqrt{(\text { 年 })}) \cdots$ 式 -5

ここに, 
$W / B^{\prime}$ : 有効水結合材比 $=W /\left(C_{p}+K \cdot A_{d}\right)$

$W$ : 単位体積あたりの水の質量 $\left(\mathrm{kg} / \mathrm{m}^{3}\right)$

$B^{\prime}$ : 単位体積あたりの有効単位結合材の質量 $\left(\mathrm{kg} / \mathrm{m}^{3}\right)$

$C_{p}$ : 単位体積あたりのポルトランドセメントの質 量 $\left(\mathrm{kg} / \mathrm{m}^{3}\right)$

$A_{d}$ : 単位体積あたりの混和材の質量 $\left(\mathrm{kg} / \mathrm{m}^{3}\right)$

$k$ : 混和材の種類により定まる定数 フライアッシュの場合, $k=0$ 高炉スラグ微粉末の場合, $k=0.7$ シリカフュームの場合, $k=0$

\section{2 酸 性 雨}

酸性雨がコンクリートに作用した場合, 酸性雨中の水 素イオンがコンクリートの細孔溶液中に存在する水酸化 物イオンと反応することによって, コンクリートのアル カリ性が失われ, $\mathrm{pH}$ 低下を生じる。酸性雨の影響を著 しく受ける場合には，pH 低下が大きくなることによっ て, セメントペーストを構成するカルシウムシリケート 水和物が分解しやすくなり, 脆化を生じてコンクリート が侵食される。これらの作用とともに鉄筋コンクリート では鋼材腐食を生じることも懸念される。また，酸性雨 中に含まれる各種のイオンによる影響, 例えば硫酸イオ ンによる膨張作用の可能性もある。

酸性雨に対する抵抗性を調べるため, 表-5に示す条 件により促進試験を実施した。その結果を図-10に示す。 この図より, 侵食深さは酸性雨の降雨時間に比例し, 50 サイクル時の侵食深さは配合によらず $1 \mathrm{~mm}$ 程度であ る。1 サイクルごとの侵食時間は 1 日であることを考慮

\section{表-5 促進酸性雨試験の条件}

\begin{tabular}{|c|c|c|c|}
\hline \multicolumn{2}{|r|}{ 項 } & 目 & 促 進 条 件 \\
\hline \multirow{3}{*}{ 浸 } & \multirow{3}{*}{ 漬 } & 溶液濃度 & $\mathrm{pH} 3.0$ \\
\hline & & 溶液種類 & 硫酸 : 硝酸 $=2: 1$ \\
\hline & & 溶液温度 & $20^{\circ} \mathrm{C}$ \\
\hline \multirow{2}{*}{ 乾 } & \multirow{2}{*}{ 燥 } & 相対湿度 & R. H. $60 \%$ \\
\hline & & 環境条件 & $20^{\circ} \mathrm{C}$ \\
\hline \multicolumn{3}{|c|}{ 環 境 } & 浸漬 1 日十乾燥 6 日 \\
\hline
\end{tabular}

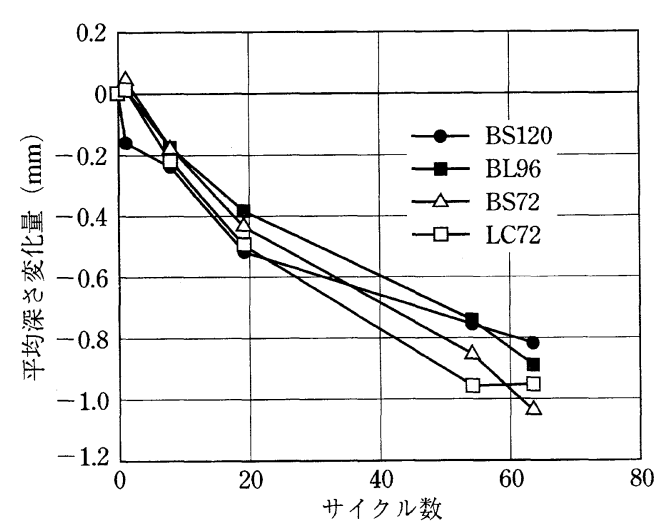

図-10 促進酸性雨試験による平均侵食深さ （※凡例の記号は表-1を参照のこと）
すると, 促進試験の結果から得られる侵食速度 $C_{0}$ は $C_{0}$ $=1 / 50(\mathrm{~mm} /$ 日 $)=7.30(\mathrm{~mm} /$ 年 $)$ となる。促進試験 の $\mathrm{pH}$ は 3.0 であり, 侵食深さは酸性雨の濃度に比例す ると考え, $\mathrm{pH}=4.6$ を基準とした侵食基準速度 $C_{p}$ は, $C_{p}=7.30 \times 10^{(3.0-4.6)}=0.183(\mathrm{~mm} /$ 年 $)$ となる。したがっ て, 自己充てん型高強度高耐久性コンクリートの酸性雨 に対する侵食速度は式-6 で求めることができる。

$$
C_{d}=C_{p} \cdot \beta_{\mathrm{pH}} \cdot \beta_{t} \cdots \cdots \cdots \cdots \cdots \cdots \cdots \cdots \cdots \cdots \cdots \cdots \cdots \cdots \cdots \cdots
$$

ここに,

$C_{d}$ : コンクリートの酸性雨に対する侵食速度 $(\mathrm{mm} /$ 年)

$C_{p}$ : コンクリートの酸性雨に対する侵食基準速度 $(\mathrm{mm} /$ 年)

$\beta_{\mathrm{pH}}$ : 酸性雨の濃度の影響を考慮するための係数 $\beta_{\mathrm{pH}}=10^{(\mathrm{pH} \mathrm{poH})}$

ここに, $\mathrm{pH}$ ：酸性雨の $\mathrm{pH}$ 值 $\mathrm{pH} 0$ ：侵食基準速度を求める際の基準。 $\mathrm{pH}$ 值で 4.6 を標準とする。

$\beta_{t}:$ 降雨量の影響を考慮するための係数 $=$ 年間総降雨時間 $\div(365 \times 24)$

\section{3 凍 結融解}

自己充てん型高強度高耐久性コンクリートの凍結融解 試験結果の一例を図-11に示した。試験は JSCE の方法 に準拠して行った。ただし, この試験方法では, 凍結融 解繰り返し数を最大 300 回としているが, ここでは, 長 期耐久性に対する検討を行うため, 相対動弾性係数が 60\%に低下するまで涷結融解を繰り返した（一部はま だ試験を継続中)。図より, フレッシュ時の目標空気量 を設計基準強度 $60 \mathrm{~N} / \mathrm{mm}^{2}$ では 4. $0 \%, 80 \mathrm{~N} / \mathrm{mm}^{2}$ では 3. $5 \%$,さらに $100 \mathrm{~N} / \mathrm{mm}^{2}$ において $3.0 \%$ に設定した 場合には, 凍結融解回数が 2500 回に達しても相対動弾 性係数は $60 \%$ を上回っている。また，これらの配合に 対してリニアトラバース法によってコンクリート硬化体 の気泡組織を分析した空気量と, 特定サイクル数を 2500 回として式-7により耐久性指数との関係を示した 屯のが図-12である。この図より, 相対動弾性係数が $60 \%$ に低下するまでの凍結融解回数を予測することが でき, 地域別の凍害危険度, 最低最高温度, 凍結融解の

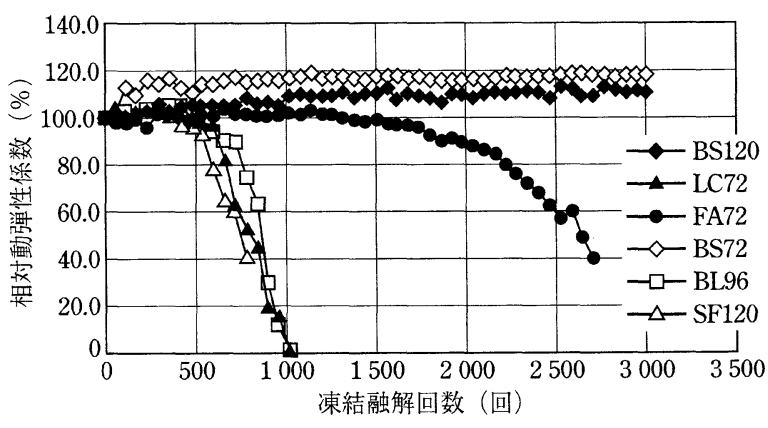

図-11 超高性能コンクリートの凍結融解サイクルと 相対動弾性係数の関係（凡例は表-1 参照） 


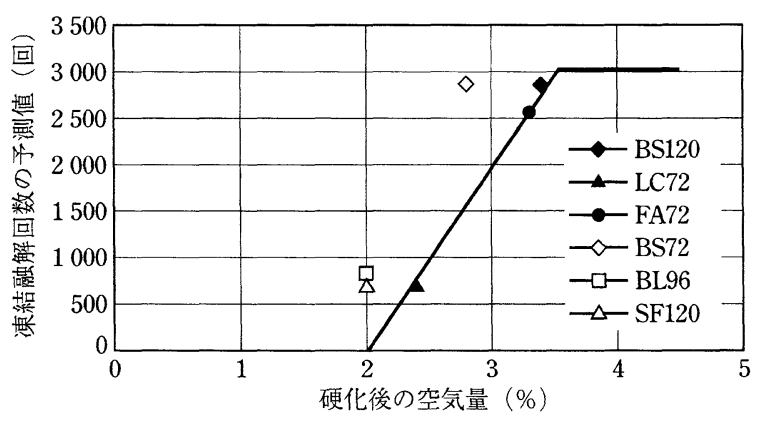

図-12 硬化後の空気量と凍結融解回数の予測値との関係

繰り返し数, 飽水度等に応じた, 必要とされる凍結融解 回数を設定することにより, 凍結融解抵抗性に対する照 査を行うことができる。

$$
D F=\frac{P \cdot N}{M}(\%)=\frac{60 \cdot N}{2500} \quad \text { 式 }-7
$$

ここに,

$D F$ : 供試体の耐久性指数

$P$ : 凍結融解 $N$ サイクルにおける相対動弾性係 数 $(\%)=60 \%$

$N: P$ の值が特定の值となるまでのサイクル数, あるいは試験を終了したときのサイクル数

$M$ : 試験を終わらせる特定のサイクル数 $=2500$ 回

5. 試設計例

\section{1 設計・施工指針（案）について}

S. Q. C 構造物開発・普及協会では, 「超高性能コンク リート構造物設計施工指針（案）平成 8 年 7 月」の改訂 版として, 性能照査型の新しい設計施工指針の作成を土 木学会コンクリート委員会に委託している。本書は現時 点で打括むね完成しており, 平成 13 年 4 月に発刊の予 定である。本指針は，「第 I 編 性能照査型設計・施工 指針」，「第 II編 設計マニュアル」，「第而編 施工マニュ アル」,「第IV編 維持管理マニュアル」,「付属書 設計 の手引きと設計例」の 5 分冊から構成されている。

全体構成は性能照査型を強く意識したものであり, 土 木学会コンクリート標準示方書の設計編と施工編をべー スにしたものとなっている。

第 I 編は，技術の進歩などの影響を受けない設計・計 画の基本事項のみを記したものである。第 II 編以降は現 時点での最新の知見に基づき書かれているが， S. Q. C 協会や他の機関での研究により新しい知見が得られた場 合には, 随時, 改訂していくべき性格のものである。ま た, 第 I編以降は相互に関連しており, 例えば, 維持管 理編は第 II, 第正編に準拠して設計, 施工が行われる ことを前提としている。

\section{2 設計の流れと設計条件}

本指針の付属書には設計例がいくつか示されているの で, その概略を紹介したい。設計例の検討フローは図-

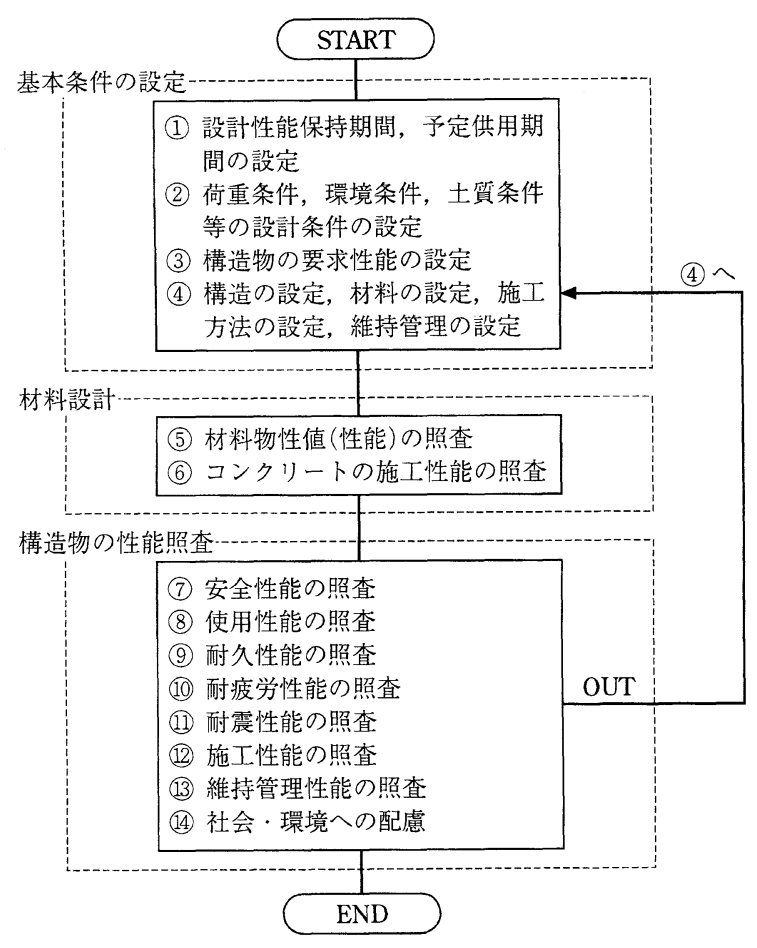

図-13 全体設計フロー

13 に示すとおりであり, 材料設計と構造物の性能照査 に大別される。材料設計では, 物性值（特性値）の設定 ならびに施工性能の照査を行い，構造物の性能照査では, 安全性能, 使用性能, 耐久性能および耐震性能などの各 要求性能の照査を行う。

性能照査型の設計においては，まず設計条件を設定し， その条件が構造物の要求性能を満足するかどうかを照査 するという手順を取る。すべての照査に合格する設計条 件をいかに早く見いだすかが，作業効率の点で重要であ るが，本設計例では，定められた設計条件に対する照査 手順を示すことに力点を置き, 照査に合格する設計条件 の効率的な推定方法については特に言及していない。設 計例で設定した設計条件の主なものは以下のとおりであ る。

- 設計性能保持期間：100 年

- 予定供用期間：300 500 年

-上部工：PRC 5 径間連続中空床版橋

・下部工：壁式橋脚，〈い基礎（場所打ちぐい）

- 環境条件 : 内陸部, 沿岸部, 寒冷地の 3 ケース（沿 岸部の海岸からの距離は $500 \mathrm{~m}$ )

・コンクリート：LC $72\left(f_{c k}{ }^{\prime}=60 \mathrm{~N} / \mathrm{mm}^{2}\right)$

- 軸方向鉄筋：USD 685，横方向鉄筋：USD 785

\section{3 性能照査結果}

安全性能および耐震性能を満足する構造の一例として, 下部工の寸法形状を図-14 に示す。施工性能については, 配筋状況等からランク 2 の自己充てん性が必要亡される のに対して, LC 72 配合はランク 2 として要求される基 準值をすべて満たしており，照査に合格する。内陸部， 寒冷地については, 表-6に示すかぶりで, 使用性能, 

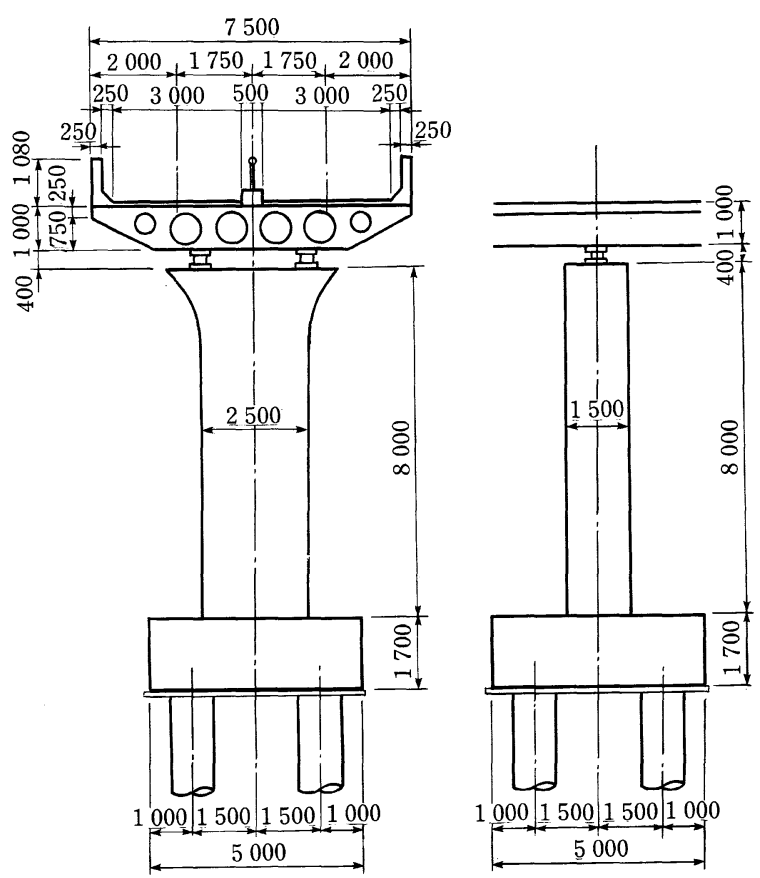

図-14 下部工の例

表-6＼cjkstart照査に用いた最小かふり

\begin{tabular}{|c|c|c|c|}
\hline \multicolumn{2}{|l|}{ 部 } & $\begin{array}{c}\text { 最小かぶり } c_{d} \\
(\mathrm{~mm})\end{array}$ & $\begin{array}{c}\text { 耐久性能の照査に用 } \\
\text { いるかぶり } c^{*} \\
(\mathrm{~mm})\end{array}$ \\
\hline \multirow{3}{*}{ 下 部 工 } & 橋 脚 & 70 & 60 \\
\hline & フーチング & 上面：70, 下面 : 110 & 上面： 60 , 下面 : 100 \\
\hline & くい & 110 & 100 \\
\hline
\end{tabular}

耐久性能のすべてを満足することが確認された。ただし， 沿岸部については，LC 72 の配合を用いても，塩害に対 して不十分な結果となった。沿岸部においては, 橋脚の かぶりを $95 \mathrm{~mm}$ 程度に確保するか表面保護工を施す等 の対策が必要となる。

\section{6. おわりに}

本文では，超高性能コンクリート（S. Q. C）構造物 の基本的な性状を把握する目的で実施された様々な試験 の中から, 構造性能については, 耐震性能, せ九断性能, 定着性能試験を取り上げ，その概要について述へた。ま
た, 耐久性能については, 一例として中性化, 酸性雨, 凍結融解に対する抵抗性の定量的評価方法について取り 上げた。さらにここれらの研究成果を取り入れた性能照 查型の設計・施工指針（案）の概要およびそれに基づく 新世代交通システム用構造物を対象とした試設計例を紹 介した。

上記の設計・施工指針（案）は平成 13 年 4 月に完成 する予定であり，誰にでも設計可能な体制が整いつつあ ると言える。このことは, S. Q. C 構造物のような耐久 性能, 耐震性能に優れた次世代の土木構造物の普及に大 きく貢献することになる。

謝 辞 本文中にて引用した構造性能試験, 耐久性能 試験は, 主に, S. Q. C 構造物開発・普及協会（正会員 23 社, 賛助会員 30 社）によって実施されたものである。 本文執筆にあたっては, 鉄建建設 菊地 眞氏, 青木建 設 牛島 栄氏, フジ夕 伊藤祐二氏, 飛島建設 田中 斉氏のご協力をいただいた。また，鉄道総合技術研究所 佐藤 勉氏, 来海 豊氏, 鳥取誠一氏からは貴重なご意 見を睗りました。ここに記して，関係者各位に多大なる 謝意を表します。

\section{参 考 文 献}

1）近藤・三島・下野・佐藤：高強度材料を用いた $\mathrm{RC}$ 部材の変形性 能評価方法に関する研究, コンクリート工学年次論文報告集, No. 3, pp. 217 222, 1999

2）近藤・三島・谷村・佐藤：高強度材料を用いた $\mathrm{RC}$ 部材の変形性 能照查方法に関する検討, 第 55 回土木学会年次学術講演会講演 概要集，V-478，pp. 958 959，2000.9

3）新田・谷村・柏原・佐藤：高強度材料を用いた鉄筋コンクリート 梁のせん断耐力に関する実験的研究, 第 55 回土木学会年次学術 講演会講演概要集，V-521，pp. 1044 1045，2000. 9

4）土屋・大内：高強度材料を用いた $\mathrm{RC}$ 梁のせん断破壊実験，第 55 回土木学会年次学術講演会講演概要集, V-520, pp. 1042 1043, 2000.9

5）伊藤・原・三島：自己充填高強度コンクリートと高強度鉄筋を用 いた部材の基本定着長に関する研究, 第 55 回土木学会年次学術 講演会講演概要集, V-577, pp. 1156 1157, 2000.9

6）手島・城国・柳・稲垣・鬼頭：超高性能コンクリートの凍結融解 および中性化に対する抵抗性に関する検討, 第 53 回土木学会年 次学術講演会講演概要集, V-339，pp. 678～679，1998. 10

7）槙島・田中・来海・津崎：超高性能コンクリートの耐酸性に関す る実験的研究，コンクリート工学年次論文集，Vol. 21, No. 2, pp. 391 396, 1999

8）佐藤・上田・出頭・手島：超高性能コンクリートの長期凍結融解 抵抗性, コンクリート工学年次論文集, Vol. 21, No. 2, pp. 385 $\sim 390,1999$ 